\title{
All Change on Aldabra
}

The Under-Secretary of State for Defence for the Royal Air Force (Mr Merlyn Rees): “. . . I want to make it abundantly clear at the outset-and this to a very large degree limits my remarks this evening-that no decision has yet been made whether or not to use the island of Aldabra for defence purposes. As my right hon. friend the Secretary of State for Defence assured the House on 5th July, the scientific issues at stake will be taken carefully into account in reaching any decision." Hansard, Col 1845, October 25, 1967.

The Prime Minister (Mr Harold Wilson): “. . In overseas terms, we have decided not to proceed with the Aldabra project-(Interruption) - the establishment of a staging post in the British Indian Ocean territory. As far as we can at present estimate, it should mean that expenditure next year will cut defence spending to the level which last July, with great difficulty, we had scheduled for 1970-71. It is an advance from 1970-71 to 1968-69-I think a remarkable achievement." Hansard, Col 1341, November 22, 1967.

available to applicants, so that only schools which regularly sent in entrants could collect papers for the aid of future candidates. (This anomaly has now been cleared away. From this year onwards the Colleges Admissions Office will deal with women's applications as well as men's.) Relations between schools such as these and the newer universities have been much stronger: Leeds University has been particularly active in sending members of its staff to talk to sixth formers. At the University of East Anglia, a report on a student's work in his first year is sent back to his school, and Sussex University gives an account to the school of how its candidates fare at the entrance interview.

This is not to say that Oxford has been entirely idle, for more and more candidates have been coming from state schools in recent years. But recruitment has largely been left to individual colleges. Last summer, the Colleges Admissions Office began arranging with a number of schools that Oxford dons should come and talk to sixth formers or staff about any problems there might be in applying to Oxford. It is hoped that the first visits may be made next term so that it might be possible to gauge the success of the scheme by the entrance figures for next year.

\section{More Big Spending}

BRITAIN should go ahead and support the plan to build the CERN $300 \mathrm{GeV}$ machine, according to Professor P. M. S. Blackett, President of the Royal Society. In his presidential address at the anniversary meeting of the society on November 30, Professor Blackett said that the big machine would provide a natural follow-up to the "brilliantly successful" $28 \mathrm{GeV}$ machine at Geneva. There was wide agreement on scientific grounds that the machine should be built, he said, but doubt had arisen because of its great cost. "Some scientists fear that the fifteen years or so forward commitment which such a big project requires could put at risk the provision of adequate finance for the great bulk of little science, which cannot be planned far ahead. After careful thought on all these matters, I am convinced that Britain should decide to join in this great and exciting European venture-and the sooner the better."

Professor Blackett went on to suggest that in reality there was no real conflict between big and little science. of course, it was possible that the demands of big science would starve little science of funds, but in
Britain this had not happened. The big spenders-nuclear physicists, high energy physicists, space scientists and radio astronomers-had beaten a path to the Treasury door and made it easy for little science to follow. "In short, the big sciences have raised the scale of expenditure on research to a new level, and this has carried little science in its wake."

Professor Blackett spoke with great enthusiasm about the increased level of exchanges within Europe, and the new arrangements for which the Royal Society is acting as a clearing house. And, in spite of the other demands on national resources, Professor Blackett said he was convinced that the rate of growth of the science budget should remain high for a long time yet. This called for very careful selection of projects for support, and some scientists were bound to feel frustrated-the biggest protests, he said, were likely to come from those who had been best fed in the past. A close comparison with manufacturing industry could be made-many firms work very hard to make their tenders for a given contract. But only one firm wins it. So it must be with British scientists, Professor Blackett concluded.

\section{Royal Society Blooming}

THE move to new premises seems to have left the Royal Society in a cheerful frame of mind even if the appeal for funds to pay for the capital cost of conversion is still some $£ 200,000$ short of the target of $£ 850,000$. In practice the programme of exchanges with European countries seems to have captured a good deal of the society's enthusiasm. The society describes its operations in the year past as "a very successful start to a new programme". There seems every prospect that the work of the past year will be increased in the months ahead and that European countries will come forward with proposals for spending money which will allow the Royal Society to draw more heavily on the British Government in support of the programme of exchanges. In the year ahead, $£ 50,000$ has been made available by the Government for this work.

Government spending through the society is increasing steadily. In the year to last April, a total of $£ 564,000$ was spent in this way, roughly a quarter of it on the support of scientific research. The society spends roughly the same amount of government money — 146,300 - on participation in international ventures, mostly through the International Council of Scientific Unions. 